\title{
Kewargaan Inklusif sebagai Paradigma Alternatif Pelayanan Publik
}

\author{
Wasisto Raharjo Jati
}

\begin{abstract}
This article traces to endeavor the concept of public services in the practice of inclusive citizenship. Contextualization of citizens should be important to be argued in order state effort to fulfilling its citizen basic needs. There are three major schools of public service regime; the liberal, social democratic, and social investment wherein each paradigm gives a different sense of the citizens. Liberal regime defines citizen guaranteed to choose their public service pattern, amidst state or market. Social democratic regime emphasizes obligatory state in terms of public services for its citizens. Meanwhile, the social investment act rationally in providing services to its citizens. The paradigm of Inclusive citizenship emerges as a form of alternative response of the third paradigm in providing public services and comprehensive democratic to every citizen. Implementation of inclusive citizenship toward public service reform is urging and significant to recommend how far and beyond state posited citizen as their client who must be served vice versa. This article will elaborate more on the meaning of inclusive citizenship in the public service.
\end{abstract}

\section{Keywords:}

Public service; citizenship; public service regime; inclusive citizenship.

\begin{abstract}
Abstrak
Artikel ini berusaha menganalisis lebih lanjut mengenai praktik kewargaan inklusif dalam pelayanan publik. Kontekstualisasi warga negara perlu sangat penting untuk dirumuskan dalam upaya negara memenuhi kebutuhan mendasar bagi warga negaranya. Dalam hal ini terdapat tiga mahzab dalam rezim pelayanan publik yakni liberal, sosial demokrat, dan investasi sosial yang mana setiap paradigma memberikan pemaknaan berbeda terhadap warga negara. Rezim liberal mendefinisikan warga negara dibebaskan untuk memilih pelayanan publik yang mereka inginkan, negara atau pasar. Sosial demokrat menintikberatkan pada kewajiban negara untuk memenuhi pelayanan publik pada warga negaranya. Sedangkan rezim investasi sosial bertindak secara rasional dalam memberi pelayanan kepada warga negaranya. Paradigma kewargaan inklusif sendiri hadir sebagai bentuk respons alternatif terhadap ketiga paradigma tersebut dalam memberikan pelayanan publik. Implementasi mengenai kewargaan inklusif terhadap reformasi pelayanan publik adalah urgen dan signifikan dalam melihat seberapa jauh dan peduli negara memosisikan warganya sebagai entitas yang harus dilayani. Artikel ini secara lebih lanjut akan menganalisis pemaknaan kewargaan inklusif dalam pelayanan publik.
\end{abstract}

\section{Kata Kunci:}

Pelayanan publik; kewargaan; rezim pelayanan publik; kewargaan inklusif.

\footnotetext{
- Peneliti di Pusat Penelitian Politik, Lembaga Ilmu Pengetahuan Indoensia (LIPI)

Email: wasisto.raharjo.jati@gmail.com
} 


\section{Pendahuluan}

Esensi pelayanan publik pada dasarnya adalah upaya negara untuk memenuhi kebutuhan mendasar warga negaranya. Adapun kebutuhan dasar itu seperti halnya redistribusi pemenuhan barang publik (public goods) yang dilakukan secara setara dan seimbang, dalam skema pembiayaan subsidiari negara melalui kebijakan public service obligation (PSO). PSO sendiri merupakan bentuk kewajiban negara secara konstitutif dan atributif memenuhi segala aspek hajat hidup semua warga negara secara komunal. Dari situlah kemudian konteks kewargaan (citizenships) menjadi penting untuk melihat relasi pelayanan publik yang dilakukan oleh negara terhadap warga negara. Dalam konteks ini, sangatlah urgen dan signifikan melihat dua premis penting yakni "rasa kepemilikan" (sense of belonging) dan juga "rasa kepemilikan" (token of membership). Kedua hal itulah yang menjadi raison d'etre negara kemudian menghadirkan pelayanan publik kepada warga negaranya. Ada semacam ikatan yang dibangun dalam relasi negara dan publik melalui konsepsi kewargaan tersebut.

Adapunperbincanganmengenaikewargaan sendiri memang sangatlah kompleks dalam segi ruang dan waktu. Pembahasan kewargaan sendiri kemudian berkembang menjadi empat ranah yakni: 1) Content of citizenship, berisikan mengenai hak dan kewajiban yang kemudian mendefinisikan seseorang menjadi warga negara. 2) Type of citizenship yakni mengacu pada pola partisipatoris dualistik bersifat sosial-politik yang hendak dijabarkan oleh negara dengan masyarakat.3) Condition of citizenship, kewargaan adalah arena relasi dan kekuasaan sosial yang memproduksi berbagai macam tindakan sosial. 4) Arrangement of citizenship, terkait instrumentasi dan operasionalisasi kewarganegaraan sendiri hendak diterapkan dan dicocoktanamkan dalam konstelasi ruang publik masyarakat (Robert, 2014:9).

Adanya berbagai macam variabel yang ada dalam konsep kewargaan (citizenships) itulah yang membuat konteks pelayanan publik sendiri menjadi penting dan menarik untuk dielaborasi lebih lanjut. Pertama, bagaimana negara kemudian merumuskan konsep kewargaan yang hendak dirumuskan dalam menghadirkan pelayanan publik kepada warga negaranya. Kedua, bagaimana kemudian karakter pelayanan publik kemudian diaktualisasikan dalam konteks riil mengenai besaran subsidiari negara. Ketiga, bagaimana negara memperlakukan warga negaranya dalam skema pelayanan publik sendiri, apakah terjadi pola diskriminasi limitatif dalam redistribusi pelayanan publik tersebut, ataukah terjadi generalisasi yang seimbang dan setara dalam pelayanan publik. Ketiga prognosis itu menjadi urgen dan signifikan untuk dilacak mengenai sifat pelayanan publik yang diberikan.

Ada redistribusi barang publik yang dilakukan secara simultan dan gradual kepada publik tanpa melihat latar belakang warga negaranya, sehingga mencerminkan kewargaan tersebut dijalankan secara inklusif. Namun, ada pula redistribusi pelayanan publik yang dilakukan secara eksklusif yakni negara bertindak setengah hati dalam memberikan pelayanan publik tersebut. Munculnya dikotomi antara inklusif maupun eksklusif tersebut bersumber dari pendefinisian warga negara sendiri oleh negara. Negara adalah pemegang kuasa otoritatif dalam menentukan individu maupun kolektif layak tidaknya masuk menjadi warga negaranya. Adapun dasar penentuan status warga negara tersebut bersumber pada parameter maupun indikator yang diterapkan oleh negara itu sendiri. Ketiga premis tersebut menjadi penting mengelaborasi lebih lanjut mengenai instrumentasi praksis kewargaan sendiri dijabarkan dalam pelayanan publik tentang bagaimana pelayanan publik tersebut dilaksanakan dan dijabarkan secara baik dan menyeluruh. Tulisan ini akan mengelaborasi lebih lanjut pengarusutamaan politik kewargaan dalam konteks pelayanan 
publik itu sendiri baik dalam segi teoritik maupun praksis.

Pembahasan mengenai praktik kewargaan inklusif sendirimenjadi penting untuk dibicarakan dalam melihat pelayanan publik sebagai perekat relasi negara dan masyarakat. Selama ini kita bisa melihat, model pelayanan publik yang dijalankan sendiri seolah hanya menaati prosedur minimalis dan mengikuti formalitas aturan saja. Padahal esensi kewargaan inklusif yang ditekankan dalam tulisan ini adalah menguatakan sense of belonging maupun sense of caring antara publik dengan negara.

Riset mengenai politik kewargaan inklusif sendiri menjadi penting untuk diteliti dalam konteks kajian sosial politik Indonesia untuk berbagai alasan. Pertama, pelayanan publik yang diberikan kepada warga negara masih bersifat diskriminatif terutama bagi kalangan minoritas. Kedua, kajian pelayanan publik Indonesia sendiri masih blurred dalam paradigmanya sehingga terkesan masih eksperimentatif. Ketiga, proses kuratif terhadap pelayanan publik, terutama dalam pelayanan publik sendiri juga belum sepenuhnya berhasil dikarenakan lokus negara yang terlalu sentral dalam mendefinisikan warga negara. Keempat, pembangunan paradigma terhadap pelayanan publik di Indonesia masih bersifateksperimentatif dan belum ada dasar yang begitu kuat. Kelima, Dimensi mengenai basis kewargaan kita belumlah sepenuhnya berbasis pelayanan, namun masih berupa pemenuhan hak dan kewajiban. Tulisan ini berusaha melacak mengenai pandangan kewargaan inklusif sebagai alternatif dalam pelaksaan pelayanan publik di Indonesia. Konteks inklusif sendiri menjadi penting dibicarakan untuk melihat proses redistribusi pelayanan publik sendiri yang dilakukan secara diseminatif sehingga semua warga negara dapat merasakan public good secara maksimal.

\section{Metode Penelitian}

Metode penelitian yang digunakan dalam riset ini adalah metode kepustakaan (library research). Analisis data dalam penelitian ini dilakukan dengan cara mengumpulkan berbagai macam sumber literatur yang relevan misalnya buku, jurnal ilmiah, prosiding, maupun artikel ilmiah lainnya yang relevan dalam penelitian (Zed, 2004: 34). Setelah semua dikumpulkan, kemudian penelitian melakukan klasifikasi data dengan cara coding untuk menemukan urgensi data yang perlu diolah terlebih dahulu baru kemudian dirangkai dengan data komplementer lainnya. Ketiga, kemudian merangkai data utama dengan dengan data komplementer tersebut sehingga dapat disusun dalam suatu naskah akademik yang padu.

\section{Dimensi Kewargaan dalam Pelayanan Publik}

Pemenuhan pelayanan publik dalam konteks kewargaan memang sangat dipengaruhi rezim regulatori negara yang bersangkutan. Adapun relasi mengenai kewargaan dan pelayanan publik secara makro banyak dipengaruhi oleh pemikiran negara kesejahteraan (welfare states) yang berkembang di kawasan Eropa Utara. Dalam skema negara kesejaheraan, adanya identitas warga negara menjadi hal penting bagi negara untuk melayani warga negaranya secara menyeluruh dan komprehensif di sana.

Negara baik secara fungsional, institusional, maupun konstitusional memonopoli adanya pelayanan publik kepada warga negaranya. Hal itu dilakukan dengan dalih bahwa negara merupakan aktor tepat dalam mendiseminasikan adanya pelayanan publik yang merata. Konteks ideologi juga berpengaruh signifikan dalam menerjemahkan konsepsi pelayanan publik dengan kewargaaan dalam level praksisnya. Lokus utamanya terletak pada pendefinisian relasi warga negara dengan negara itu sendiri. Harus diakui, relasi kedua entitas tersebut berdasarkan relasi patrimonialisme yang dibangun melalui mekanisme take and give. Namun hal itu tidak 
menjadi an sich berlaku tetap dan umum di berbagai negara di dunia.

Terdapat tiga anasir untuk menjelaskan relasi ideologis tersebut yakni: 1) Warga negara akan dianggap sebagai entitas yang mandiri sementara negara hanya berperan sebagai penjaga malam. Pelayanan publik kemudian diserahkan kepada mekanisme pasar untuk memastikan adanya kendali mutu dalam pemberian pelayanan public. 2) Warga negara menjadi entitas yang mendapatkan protektorat penuh dari negara sehingga negara secara absolut menentukan dan mencukupi kebutuhan hidup warga negaranya. 3) Negara bertindak minimalis atas pelayanan kepada warga negara dan lebih menyerahkan kepada mekanisme komunal. Maka dari ketiga anasir tersebut, kita bisa mengelaborasi lebih lanjut mengenai rezim karakter pelayanan publik yang dibangun dalam setiap negara.

Adapun negara regulatoris dalam pelayanan publik sendiri terbagi atas tiga bentuk yaitu rezim negara liberal, rezim negara sosial demokrat, dan rezim negara investasi sosial (Andersen, 1990: 95). Pertama, rezim negara liberal melihat konteks pelayanan publik sebagai perkara pilihan (choices) bagi warga negara. Dalam hal ini, mekanisme pemberian pelayanan publik terbagi atas penyelenggaran pelayanan publik yang diselenggarakan oleh Negara, dengan mekanisme pelayanan publik yang diselenggarakan oleh negara. Negara hanya bertindak sebagai operator untuk memastikan adanya diseminasi yang seimbang dan merata dalam pemberian pelayanan publik yang diselenggarakan oleh pasar.

Pasar sendiri bertindak sebagai eksaminator yang menjalankan perintah negara untuk menghadirkan pelayanan publik yang baik dan memadai. Hadirnya pasar sebagai aktor dalam manajemen pelayanan publik menunjukkan tidak adanya monopoli dalam pelayanan publik. Negara memandang hadirnya pasar dalam mekanisme pelayanan publik sebagai bagian dari asistensi pasar kepada negara. Negara mengakui apabila pelayanan publik terlalu dibebankan semuanya kepada negara, justru akan membuahkan ketidakefektif dan ketidakefisiensian terhadap kualitas pelayanan publik. Hadirnya pasar dalam pelayanan publik berguna untuk menguatkan peran negara.

Lokus permasalahannya kemudian adalah pendefinisian mengenai warga negara. Warga negara adalah bentuk membership yang diberlakukan oleh negara, namun apabila pelayanan publik dilaksanakan oleh pasar, warga negara justru akan diperlakukan sebagai konsumen. Logika yang berlaku adalah demand and supply di dalam diseminasi pelayanan publik. Artinya terjadi pola excludiary dan eksklusif apabila terdapat warga negara yang tidak mampu memberikan cukup uang untuk mendapatkan pelayanan publik.

Beberapa contoh negara yang mengedepankan praktik kewargaan berbasis pelayanan publik adalah negara-negara yang berbasiskan budaya Anglo Saxon seperti Inggris, Australia, Selandia Baru, dan lain sebagainya. Berkembangnya praktik kewargaan liberal di berbagai kawasan tersebut mengindikaskan adanya iklim kompetitif dan rasional ekonomi yang begitu menguat, di dalam spirit individualisme setiap warga negaranya (Manow, 2001:6). Hadirnya bentuk rezim regulatori yang berbasiskan pada liberal memang mendaraskan diri kepada bentuk kewargaan liberal.

Pandangan kewargaan liberal sendiri mendaraskan pada konsepsi citizen as object yakni warga negara sebagai aktor utama dalam negara. Hubungan dengan negara sendiri pada dasarnya bersifat atributif yaitu negara menjadi politik identitas umum bagi warga negara. Konteks terpenting adalah negara memberikan perlakuan inklusif untuk warga negara untuk mengembangkan dirinya sendiri, baik dalam skala individu maupun kolektif. Maka konteks pelayanan publik liberal sangat menekankan pada konteks choices sebagai dasar pilihan 
berpolitik. Munculnya konteks pengalaman pelayanan publik liberal sendiri berasal dari pengalaman revolusi industri yang berkembang di sana. Adanya revolusi industri itulah yang menjadikan konteks kewarganegaraan sendiri menjadi lebih eksklusif berdasarkan pada kepemilikan modal dan alat produksi.

Konteks pasar tidak selalu menjadi tempat alternatif dalam penyediaan pelayanan publik an sich, selain halnya negara. Leslie Seidle (1995) dalam karyanya yang berjudul Rethinking Delivery of Public Service menengahkan peranperan organisasi sosial nonpemerintah bisa menjadi mediasi dalam pemberian kebijakan publik. Peran organisasi sosial berbasiskan komunitarian ini menjadi jalan keluar dari monopoli negara maupun eksklusifitas pasar dalam memberikan pelayanan publik. Peran organisasi sosial sendiri bisa diejawantahkan dengan mengurangi biaya dan peran negara, mengontekskan antara kebijakan publik dengan aspirasi publik. Namun, yang menjadi pertanyaan kritis lanjutan adalah pelayanan publik model komunitarian bisa melakukan cover atas keseluruhan biaya pelayanan publik atau tidak. Pengalaman pelayanan kesehatan yang dilakukan oleh British Columbia, At Home, mengindikasikan adanya partisipatoris yang digerakkan secara filantropis oleh semua kalangan publik untuk melayani kepentingan bersama. Namun hal itu dilakukan berdasarkan satu rasa dalam pelayanan publik.

Kedua, rezim regulatori kedua tentang pelayanan publik adalah rezim sosial demokrat. Rezim ini memegang garis idelologi kiri tengah yang menempatkan kesetaraan dan pemenuhan HAM setiap warga negaranya. Negara melihat bahwa warga negara merupakan entitas yang perlu untuk dilindungi dan dijaga hak dan kewajibannya, karena warga negara adalah sekolompok manusia yang rentan. Adanya paradigma tersebut mendorong negara agar merasa perlu mendorong diri agar lebih proaktif dan reaktif dalam pemenuhan kebutuhan layanan warga negara. Garis ideologi yang digunakan, yakni kiri tengah, merupakan bentuk dominasi politik yang dilakukan oleh partai buruh sebagai partai berkuasa. Kepemimpinan partai buruh inilah yang kemudian menciptakan kebijakan pajak progresivitas dalam skema pemberian subsidi silang kepada yang tidak mampu.

Dampak positif dari pengedepanan praktik kewargaan ini adalah pemenuhan praktik kewargaan menjadi maksimal, karena negara menjamin semua hak dan kewajiban setiap warga negaranya. Namun demikian, hal terpenting dalam menelisik pemenuhan pelayanan publik berbasis kewargaan sosial demokrat ini adalah dimensi sustainibilitas maupun durabilitas negara, dalam menjamin keberlangsungan pemenuhan basic needs oleh negara. Negara melalui rezim sosial demokrat menggunakan pendekatan produktif dan preventif.

Pendekatan produktif adalah negara melalui skema pemberian subsidi negara maupun subsidi silang menerapkan investasi sosial baik di bidang pendidikan maupun kesehatan. Negara menyadari bahwa subsidi yang dikucurkan adalah hasil dari perekonomian berbasis sumber daya manusia yang unggul, baik secara intelektual maupun kesehatan, yang akan lebih produktif untuk menopang skema negara kesejahteraan untuk bisa bertahan dalam waktu lama. Besarnya pengeluaran subsidi yang diberikan oleh negara juga merupakan aksi preventif agar tidak terjadi ketimpangan dalam pemberian subsidi pelayanan publik. Hal yang kurang dari adanya jaminan penuh terhadap layanan publik itu adalah warga negara tidak memiliki kebebasan dalam memilih layanan publik yang diinginkan karena semua dimonopoli oleh negara. Jika menggunakan struktur yang lebih baik, maka akan ada persamaan terhadap standar dan kualitas pelayanan publik yang akan diperoleh warga negara.

Rezim regulatori pelayanan publik yang memberlakukan sistem sosial demokratis 
ini terjadi pada kasus negara-negara Skandinavia seperti Denmark, Finlandia, Swedia, maupun Islandia. Negara-negara tersebut merupakan negara industri maju dengan tingkat pendapatan yang tinggi. Hal itu berimplikasi pada melimpahnya dana sosial yang dikumpulkan, dari hasil pajak progresif yang dikumpulkan korporasi, untuk membiayai pelayanan publik. Meskipun dalam kondisi serba berlimbah, namun tetap perlu mewaspadai potensi penduduk tua yang semakin bertambah. Harus diakui bahwa dengan berbagai kenyaman yang diberikan oleh negara, penduduk usia tua menjadi makin bertambah. Kondisi tersebut menjadi beban bagi penduduk muda untuk menjadi tumpuan subsidi atas pelayanan publik yang diberikan oleh negara. Oleh karena itu, dalam praktik kewargaan, kondisi tersebut justru akan menjadi ancaman laten. Akan muncul adanya kesenjangan antara warga negara manula yang diposisikan sebagai privileged dengan warga negara usia muda yang neglected.

Pelayanan publik berbasiskan pada sosial demokratis ini simetris dengan konsepsi kewarganegaraan sosial. Konsep kewarganegaraan sosial menekankan pada hubungan kesetaraan dan keadilan terhadap semua manusia, yang kemudian termanifestasikan dalam hubungan kerja. Kerja menjadi indikator dalam mengukur kewargaan seseorang untuk melihat seberapa kontribusi yang dihasilkan kepada negara. Adanya parameter itulah yang kemudian menciptakan adanya dikotomi warga negara yang skilled artisan dengan warga negara yang non skilled artisan (Robert, 2014:81).

Adanya dikotomi tersebut bukanlah untuk menghasilkan fragmentasi dalam layanan publik. Akan tetapi lebih pada kondisi pemenuhan kebutuhan filantropis untuk mencukupi kebutuhan anggaran bagi negara. Dalam konsepsi kewarganegaraan sosial, semua warga negara adalah gentleman. Gentleman di sini bermakna setiap komunitas kelas masyarakat yang sudah dideterminasi oleh sistem ekonomi yang sudah pasti dan ajeg. Dalam analogi Marshall disebutkan bahwa kewarganegaraan sosial merupakan bentuk emansipasi ekonomi dalam sebuah masyarakat ekonomi kompetitif. Hal ini dikarenakan dalam struktur masyarakat yang kompetitif, pengejaran terhadap pendapatan merupakan bentuk rasionalitas politik yang selalu saja dilakukan. Kondisi tersebut yang kemudian menimbulkan adanya dehumanisasi terhadap manusia yang semula adalah citizen kiniberubah menjadi labor. Oleh karenanya, konsepsi negara kesejahteraan sendiri merupakan proyek besar untuk mewujudkan emansipasi di antara berbagai warga negara.

Ketiga, rezim regulatori yang berbasiskan pada investasi sosial sebenarnya merupakan bentuk kompromistis dari pelayanan publik berbasi kewargaan liberal dengan berbasis kewargaan sosial demokratis. Negara tidak terlalu mengontrol penuh layanan publik karena dibantu oleh pasar sebagai aktor sampirannya. Negara menyadari bahwa pelayanan publik yang berwujud pada public goods tidak bisa dipukul rata dan hasilnya tidak bisa dirasakan secara menyeluruh oleh publik.

Logika investasi sosial lebih dititikberatkan pada logika ekonomi futuristik. Negara melalui skema pembiayaan subsidi maupun dengan asistensi pasar, sebenarnya menjadikan warga negara sebagai aset untuk menjamin kontinuitas skema pelayanan publik. Hal ini juga merupakan bentuk koreksi sekaligus revisi terhadap skema pelayanan publik yang berdasarkan paradigma sosial democrat, yang justru menimbulkan boom aging yang terlalu besar. Kondisi tersebut terjadi akibat investasi pada pelayanan publik yang besar namun tidak dibarengi dengan stimulus terhadap penduduk usia muda.

Pasar hadir untuk memberikan alternatif dalam pilihan layanan publik, selain yang diberikan oleh negara. Negara dan anggaran 
secara strategis diuntungkan dengan hadirnya pasar ini karena secara ekonomis akan mereduksi pengeluaran negara. Sikap kompromistis tersebut memunculkan varian lain terhadap pemaknaan kewargaan dalam pelayanan publik. Dalam skema pelayanan publik berbasis kewargaan liberal disebutkan bahwa warga negara adalah entitas otonom, hak dan kewajibannya dipenuhi dan dilindungi oleh negara. Warga negara adalah figur yang rasional dalam pengejaran materi sehingga mekanisme self servicing digunakan untuk memperoleh pelayanan publik yang lebih baik dan memadai.

Dalam taraf ini, kewargaan yang sedang dikembangkan adalah merevitalisasi konsep liberalisme sekaligus pula kolektivisme.
Liberalisme sendiri tetap menjaga adanya kedaulatan warga negara untuk bebas mengekspresikan semua artikulasi dan ekspresi kepentingannya. Sedangkan kolektivisme menempatkan negara agar tetap berada dalam marwahnya, untuk tetap menjaga warga negara sebagai bentuk politik proteksionisme. Jika ditelisik lebih lanjut dan mendetail, relasi antara pelayanan publik dengan politik kewargaan dapat dianalisis dalam tabulasi Tabel 1.

Jika dielaborasi lebih lanjut, desain kewargaan yang ditawarkan dalam pelayanan publik bervariasi. Dalam kultur Anglo Saxon, paradigma citizen as subject sangat ditonjolkan. Publik sebagai warga negara adalah otoritas otonom, bisa melayani diri sendiri dengan

Tabel 1.

Relasi Mahzab Politik Kewargaan dengan Pelayanan Publik

\begin{tabular}{|c|c|c|c|}
\hline No & $\begin{array}{c}\text { Mahzab Pelayanan } \\
\text { Publik }\end{array}$ & $\begin{array}{c}\text { Relasi Politik } \\
\text { Kewargaan }\end{array}$ & Karakter Pelayanan Publik \\
\hline 1 & $\begin{array}{l}\text { Rezim Pelayanan } \\
\text { Publik Liberal }\end{array}$ & Kewargaan Liberal & $\begin{array}{l}\text { - Mekanisme pasar menjadi eksaminator } \\
\text { - Lelayanan publik } \\
\text { - dalam pelayanan publik } \\
\text { - Mekanisme choices sebagai bentuk politik } \\
\text { deliberasi dalam pelayanan publik } \\
\text { - Pelayanan bersifat eksklusif dan excludiary } \\
\text { sehingga menjadikan public goods tidak } \\
\text { terdistribusi dengan baik. }\end{array}$ \\
\hline 2 & $\begin{array}{l}\text { Rezim Pelayanan } \\
\text { Publik Sosial } \\
\text { Demokratis }\end{array}$ & $\begin{array}{c}\text { Kewargaan } \\
\text { Republikanisme }\end{array}$ & $\begin{array}{l}\text { - Negara tampil sebagai regulator dan } \\
\text { eksaminator terhadap pelayanan publik } \\
\text { kepada warga negara } \\
\text { - Warga negara mendapatkan fully subsidiaries } \\
\text { terhadap pelayanan publik maupun basic } \\
\text { needs yang mereka butuhkan. } \\
\text { - Warga tidak bisa mendapatkan nilai lebih } \\
\text { terhadap pelayanan publik yang mereka } \\
\text { terima, meski telah membayar pajak } \\
\text { progresif. }\end{array}$ \\
\hline 3 & $\begin{array}{l}\text { Rezim Pelayanan } \\
\text { Publik Investasi } \\
\text { Sosial }\end{array}$ & $\begin{array}{l}\text { Kewargaan Liberal } \\
\text { dan Republikanisme }\end{array}$ & $\begin{array}{l}\text { - Negara bertindak minimalis dan bersinergi } \\
\text { dengan pasar dalam menciptakan pelayanan } \\
\text { public yang adil } \\
\text { - Negara tampil sebagai regulator dan pasar } \\
\text { sebagai eksaminator. }\end{array}$ \\
\hline
\end{tabular}

Sumber: Robert, 2014 E Andersen, 1990 
risorsis ekonomi maupun alat produksi yang mereka punya. Negara dalam hal ini bertindak minimalis, berfungsi sebagai penjaga malam dan memberikan mandat pada pasar sebagai eksamintor redistribusi public goods tersebut.

Adapun dalam kultur sosio-demokratis, paradigma kewargaan sebagai citizen as object sangat ditekankan. Negara tampil dengan menjalankan praktik governabilitasnya secara total, dengan menerapkan subsidi penuh atas pemenuhan basic needs warga negaranya dengan dana pajak progresif. Negara mendefinisikan pelayanan publik yang diberikan kepada warga negaranya secara absolut. Sedangkan dalam rezim investasi social, negara bertindak sebagai fasilitator dengan memberikan pilihan bagi warga negara untuk mendapatkan pelayanan publik terbaik, seperti yang mereka minta.

Pendefinisian kewargaan yang masih terdikotomi antara citizen dengan customer menjadikan pola kewargaan menjadi eksklusif. Ditinjau dari segi pemahaman citizen, negara bertindak secara absolut dalam menentukan dan mendefinisikan berbagai parameter dari sebuah token of membership, afiliasi publik dengan negara. Adanya absolutisme negara inilah, tidak jarang menciptakan warga minoritas yang tidak dilayani hak dan kewajiban kewargaannya secara penuh. Persoalan minoritas tersebut berkaitan dengan elemen kelompok warga negara yang tidak memenuhi kriteria kewargaan, yang dirumuskan oleh negara.

Dalam berbagai kasus di Indonesia, bisa dianalisis ada kelompok-kelompok minoritas yang sepenuhnya belum dipenuhi haknya seperti komunitas Samin, Kaharingan, maupun komunitas lainnya karena perbedaan agama dan kepercayaan. Begitu pula di negara lain seperti Kamboja dan China, masalah minoritas lebih didasarkan pada perbedaan ras.

Sedangkan apabila meninjau lebih lanjut mengenai pelayanan publik yang dilaksanakan pasar, letak eksklusif ada pada logika supply and demand. Hal ini dikarenakan bentuk pemberian pelayanan publik dilaksanakan dengan cara membeli. Konteks membeli ini sangat erat kaitannya dengan privatisasi public goods sebagai komoditas dagang. Parameter keanggotaan dalam memperoleh pelayanan publik memang menjadi sederhana dan ringkas, yakni dengan kepemilikan materi ditukar dengan public goods sesuai kadar materi yang dimiliki. Pelayanan publik yang ditentukan oleh kadar pembayaran ternyata membuahkan stratifikasi sosial, implikasinya adalah muncul dikriminasi antar elemen publik. Penduduk kaya mendapatkan pelayanan publik yang memuaskan. Sedangkan penduduk miskin mendapatkan pelayanan publik sesuai kadarnya, bahkan tidak memuaskan.

Gambaran eksklusif berujung diskriminasi tersebut berlanjut pada prinsip dan ideologi kewargaan yang dianut. Ambiguitas itulah yang nantinya menciptakan pola privileged and neglected di antara warga negara. Perubahan paradigma menuju proses governance tidak berpengaruh signifikan dalam pemberian pelayanan publik yang baik. Reformasi birokrasi dalam pelayanan publik yang digalakkan melalui norma New Public Management maupun New Public Service sesuai anasir Osborne maupun Geabler juga belum berpengaruh signifikan (Jati, 2011: 70).

Tesis reinventing government sendiri pada dasarnya merupakan bagian dari cara mereformasi manajemen pemerintahan, baik dari upper level government hingga street level government secara lebih terbuka dan responsif. Hasilnya, reformasi birokrasi yang diterapkan tidak sepenuhnya tercapai karena patologi birokrasi yang masih ditemukan, seperti masih kuatnya paradigma pangreh daripada pamong oleh birokrasi dalam melayani publik. Berbagai eksperimentasi mengenai nalar dan metode pelayanan publik yang belum sepenuhnya usai inilah yang mendorong terciptanya pola pelayanan publik yang inklusif, dengan relasi kewargaan yang cair.

Eksperimentasi yang beragam itu sebenarnya telah dicoba dengan basis 
komunitarian, voluntarianisme, maupun forum. Namun belum menjadi level praksis, karena perlu dirumuskan terlebih dulu desain ontologi pelayanan public yang berbasis kewargaan inklusif. Besarnya pengaruh negara dalam mendefinisikan keanggotaan maupun parameter sebuah warga negara inilah yang melahirkan gerakan kontra dalam pelayanan publik berbasis komunitas. Bentuk pelayanan publik ini lebih bersifat kesukarelaan daripada mengikat dengan parameter.

\section{Urgensi Kewargaan Inklusif dalam Pelayanan Publik}

Kewargaan inklusif pada dasarnya hadir sebagai bentuk resistensi terhadap dikotomi pola kewargaan, yang diterapkan selama ini. Kewargaan liberal justru menjadikan konteks homo homini lupus membesar karena manusia saling berkontestasi demi mengejar pelayanan publik terbaik. Kewargaan republikanisme menjadikan konteks homo sacers meninggi karena kemampuan produksi warga negara dibatasi, karena semuanya telah dipenuhi oleh negara. Dari dua anasir tersebut, bisa dikaji mengenai pemaknaan pelayanan publik yang selalu terganjal oleh persoalan ajudikasi kepentingan kelompok tertentu atas kelompok lainnya. Kondisi dialektis tersebut menciptakan persoalan mayoritas maupun minoritas, yang seringkali tereskalasi dengan cepat dan menyebar.

Anasir mengenai mayoritas dan minoritas berpulang kembali pada sumbangsih dan partisipasi. Konteks tersebut berkonsentrasi kepada menguatnya problematika human security di era modern sekarang ini, menggantikan traditional security berbasis negara. Negara dipandang mengalami degradasi dalam menjalankan fungsinya, dalam operasionalisasinya melalui transisi government menuju governance (Pratikno, 2005: 232-235). Governance mengindikasikan adanya partisipatorisme warga negara dalam proses pemerintahan, disamping halnya peran pasar.
Pasar maupun masyarakat merupakan aktor independen yang ikut andil dalam membangun negara. Oleh karena itu, basis identitas yang selama ini dipahami secara an sich, sebagai bentuk pelaksanaan kewargaan yang atributif dan melekat, perlu dirumuskan ulang.

Teorisasi Marshall yang mengangkat tema gentleman pun patut untuk dianalisis mengenai kontribusi warga dalam negara. Gentleman sendiri mendefinisikan setiap warga negara adalah pihak rasional dan mampu bekerja sama, bukanlah dimensi pajak maupun materi. Namun seberapa penting negara berpartisipasi dalam setiap kegiatan aktif dalam penyelenggaraan negara. Negara tidaklah statis namun juga perlu proaktif dalam menyambangi kebutuhan masyarakatnya. Logika street level government yang menekankan aspek pelayanan langsung kepada masyarakat. Sinergisitas itulah yang perlu dikembangkan dalam membentuk pola kewargaan inklusif, oleh dua pihak yakni negara dan publik, dalam mewujudkan kerjasama yang dinamis.

Kewargaan inklusif merupakan konsepsi mendaraskan pada perubahan kewargaan berbasis hak dan kewajiban (state citizenship) menjadi pola kewargaan yang berbasis pelayanan maupun partisipatoris (participatory citizenship). Era kewargaan partisipatoris adalah sebentuk gejala post-modern di dunia tentang konsepsi partisipatoris itu sendiri. Dalam pandangan liberal, komunitarian, maupun multikultural melihat bahwa esensi negara adalah sang causa prima dalam perumusan kewargaan bagi warga negaranya, karena sama-sama menuju pada pengejaran kebaikan bersama (common goods) (Gaventa, 2002:7). Hal itulah yang membedakannya dengan desain kewargaan partisipatoris yang lebih mengutamakan pada kebajikan warga negara (civic virtue).

Jika menyimak diferensiasi dua pola tersebut, kewargaan inklusif adalah anti tesis dari pola kewargaan negara. Perkembangan kewargaan negara memang berangkat dari situasi pasca-otoritarian, transisi terjadi dari 
Tabel 2.

Varian Kewargaan dalam Pelayanan Publik

\begin{tabular}{ll}
\hline \multicolumn{1}{c}{ Kewargaan Negara (state citizenship) } & Kewargaan Partisipatoris (participatory \\
citizenship)
\end{tabular}

Sumber: Karjuni, 2010 \& Robert, 2014

negara represif menjadi demokratis. Pelayanan publik menjadi corong utama dalam mekanisme penerapan demokrasi tersebut, namun hal itu tidak dibarengi dengan reformasi birokrasinya. Alhasil dalam pemberian pelayanan publik, birokrasi menjadi aktor yang tidak demokratis karena hanya menghamba dirinya sendiri.

Hal itu membuat konteks warga negara yang semula ditempatkan sebagai pemegang mekanisme kedaulatan menjadi tidak berguna. Eksperimentasi terhadap model pelayanan publik demokratis dengan menjadikan warga negara sebagai raja, melalui model reinventing government dengan menginjeksi nilai-nilai pasar dalam pelayanan publik juga tidak berpengaruh signifikan, dalam mendemokratiskan pelayanan publik yang adil. Sedangkan logika New Public Service kini juga belum berpengaruh signifikan dalam pemberian pelayanan publik. Terdapat berbagai kendala dalam merumuskan new public services, yaitu: 1) Pemerintah masih ambigu dalam perumusan warga negara, jika ditinjau dari segi konstitusi yakni UU No. 12 Tahun 2006, menujukkan bahwa basis kewarganegaraan masih mengandalkan us sanguinis (berbasis darah) maupun ius soli (berbasis tanah). Kedua kriteria itu adalah kategorisasi klasik dalam perumusan kewargaan, basis spasial-geografi masih menjadi penentu utama.
2) Diseminasi publik untuk menunjukkan sikap kritisisme dan partisipatoris dalam pelayanan publik demokratis juga belum sepenuhnya menyeluruh. Publik masih apatis sebagai warga negara yang independen dan otonom, dalam menyuarakan aspirasinya terkait pelayanan publik yang dimiliki. 3) Mekanisme pemberian pelayanan publik maupun redistribusi public goods masih terhambat pada pemberian rente yang belum sepenuhnya selesai. Birokrasi masih menunjukkan gejala patologis untuk melayani dirinya sendiri.

4) Masih ditemukan diskriminasi, terutama bagi kalangan minoritas untuk mendapatkan pelayanan serupa dengan kalangan mayoritas, baik dari segi regulasi maupun luaran barang. 5) Peluang munculnya diskresi dalam pelayanan publik selain halnya munculnya pelayanan publik berbasis komunitarian dan lain sebagainya. Artinya dengan melihat beberapa permasalahan tersebut, secara sistemik implementasi kewargaan masih menemui berbagai macam kendala. Adapun dalam rezim administratif, kewargaan inklusif juga terkendala dengan berbagai parameter kewargaan yang kaku. Hal ini merupakan tantangan dari pelaksanaan kewargaan inklusif. 


\section{Best Practice dan Citizen Charter sebagai Solusi}

Dalam beberapa tahun mutakhir ini, diskursus mengenai logika best practice dan citizen law charter mulai digalakkan di sektor pelayanan publik. Kedua paradigma tersebut menjadi trendsetter dalam mendemokratiskan pelayanan publik kepada warga negara, sebagai respons gagalnya pasar dalam mengelola public goods (Kumorotomo, 2007: 7). Kegagalan pasar menjadikan resistensi publik menguat untuk mengontrol dan mengawasi jalannya pelayanan publik, melalui jalur advokasi dan ajudikasi kepentingan. Advokasi menjadi bagian dari aksi kewargaan aktif, untuk menilai sejauh mana negara melayani kebutuhan mereka (Karjuni, 2010: 40).

Logika yang dibangun dalam mekanisme dua paradigma tersebut sebenarnya adalah membangun partisipasi warga negara. Hal ini juga bagian dari upaya mereduksi pengaruh patronase dalam pelayanan publik oleh aparat birokrasi. Secara terminologis, best practice diartikan sebagai bentuk pelayanan terbaik yang dilakukan oleh aparat negara kepada publik melalui pola transparansi yang dilakukan kedua belah pihak. Tujuannya adalah membangun relasi dan kepercayaan di antara kedua belah pihak, agar proses redistribusi public goods dilakukan dengan baik dan detail.

Lokus pembangunan kepercayaan (trust building) menjadi konsentrasi utama dalam hal ini, mengingat model pengelolaan pelayanan publik yang sebelumnya sangat timpang dan diskriminatif. Best practice merupakan upaya untuk mereduksi citra aparat dan sistemnya yang selama ini negatif, untuk lebih responsif dan kuratif dalam memenuhi kepentingan publik. Oleh sebab itu, best practice menjadi bagian dari proses pembentukan kewargaan yang aktif, untuk mendorong publik ikut mengawasi jalannya public goods.

Pemaknaan citizen charter juga bisa diartikan sebagai bentuk afirmasi komitmen pemerintah, dalam meningkatkan pelayanan publiknya kepada masyarakat luas. Hal terpenting dalam memahami citizen charter adalah standardisasi maupun pelayanan prima. Kedua hal itu menempatkan penduduk sebagai entitas yang perlu untuk segera dihubungi. Kekuatan pemaksanya terletak pada pembayaran pajak yang menjadi hak publik untuk mendapatkan pelayanan publik prima.

Pelayanan publik yang berbasiskan best practices merupakan manifestasi dari upaya kuratif New Public Service yang digalakkan pada pertengahan 2006. Dalam hal ini, upaya instrumentasinya terganjal oleh kesiapan pemerintah dalam menerima berbagai macam kritikan dan masukan publik. Hal ini menjadikan pemerintah merevisi sistem maupun aturan yang berlaku secara komprehensif. Best practice adalah bagian dari penguatan kapasitas dalam mengubah manajemen diri, baik itu melalui twinning dengan swasta atau transforming dengan berbagai bentuk kebutuhan masyarakat. Pembenahan maupun restrukturisasi manajemen pelayanan publik melalui logika best practice merupakan bagian pembenahan dari sektor hulu. Pemerintah perlu menginklusifkan diri dengan menjadi bagian dari proses kewargaan publik yang aktif dan partisipatoris.

Sedangkan esensi dari citizen charter yaitu bagian dari usaha mendorong publik agar lebih proaktif ke dalam ranah negara. Selain mendorong partisipasi, paradigma ini juga mendorong proses negosiasi maupun advokasi warga negara kepada negaranya, terkait pelayanan publik. Semua itu terdukung oleh keterbukaan informasi publik melalui e-government. Advokasi maupun negosiasi adalah hal terbarukan dalam membentuk kultur warga negara yang aktif, baik dalam skala komunitarian maupun individual. Bahkan tak tertutup kemungkinan tercipta pelayanan publik komunitarian yang difasilitasi negara. Negosiasi dimaknai sebagai proses tawar 
menawar pola redistribusi, bentuk pelayanan, maupun metode pembayaran atas pelayanan publik tersebut.

Adanya negosiasi maupun aksi advokasi yang dilakukan oleh warga negara merupakan sebentuk proses kontrak kinerja, yang dilakukan publik kepada penyedia layanan. Dimensi kontrak mengindikasikan adanya penerapan teori Rosseau, tentang kontrak sosial dalam pelayanan publik, menempatkan posisi publik dengan negara adalah sederajat. Kesamaan derajat tersebut dimanifestasikan dengan kemitraan yang dibangun antar kedua aktor tersebut. Pemosisian sebagai mitra adalah upaya menjadikan transparansi maupun keterbukaan sebagai modal penting dalam membangun pelayanan publik. Secara eksplisit, paradigma mengenai citizen driven lebih menguat daripada customer driven, terdapat proses menghargai publik sebagai warga negara yang perlu dilayani. Jika divariabelkan secara atas dan bawah, logika pelayanan publik melalui best practice maupun citizen charter ini dapat dikerangkai dalam tabulasi seperti pada Tabel 3.

Tabulasi di atas menggambarkan adanya penyerapan nilai-nilai inklusif, baik dari segi best practice maupun citizen charter untuk mewujudkan pelayanan publik yang baik. Publik sebagai penerima dan pengontrol operasionalisasi melalui advokasi dan negosiasi. Sedangkan pemerintah selaku provider melakukan reformasi sistemik atas model pelayanan publik yang akan dijalankan kemudian. Model kewargaan inklusif ini tidak serta merta dapat dijalankan secara general dan komprehensif di berbagai tempat. Sejauh ini, model pelayanan inklusif berhasil dijalankan di Kabupaten Jembrana-Bali, Kalimantan Timur, DKI Jakarta, Surakarta, dan Yogyakarta. Selebihnya, model yang dijalankan masih berkutat pada pola korupsi maupun kolusi yang dilakukan birokrasi rente. Masih belum meratanya diseminasi praktik kewargaan inklusif merupakan tantangan tersendiri, yang perlu dibenahi ke depannya.

Tabel 3.

\section{Sinergisitas Nilai-nilai Kewargaan Inklusif dalam Pelayanan Publik}

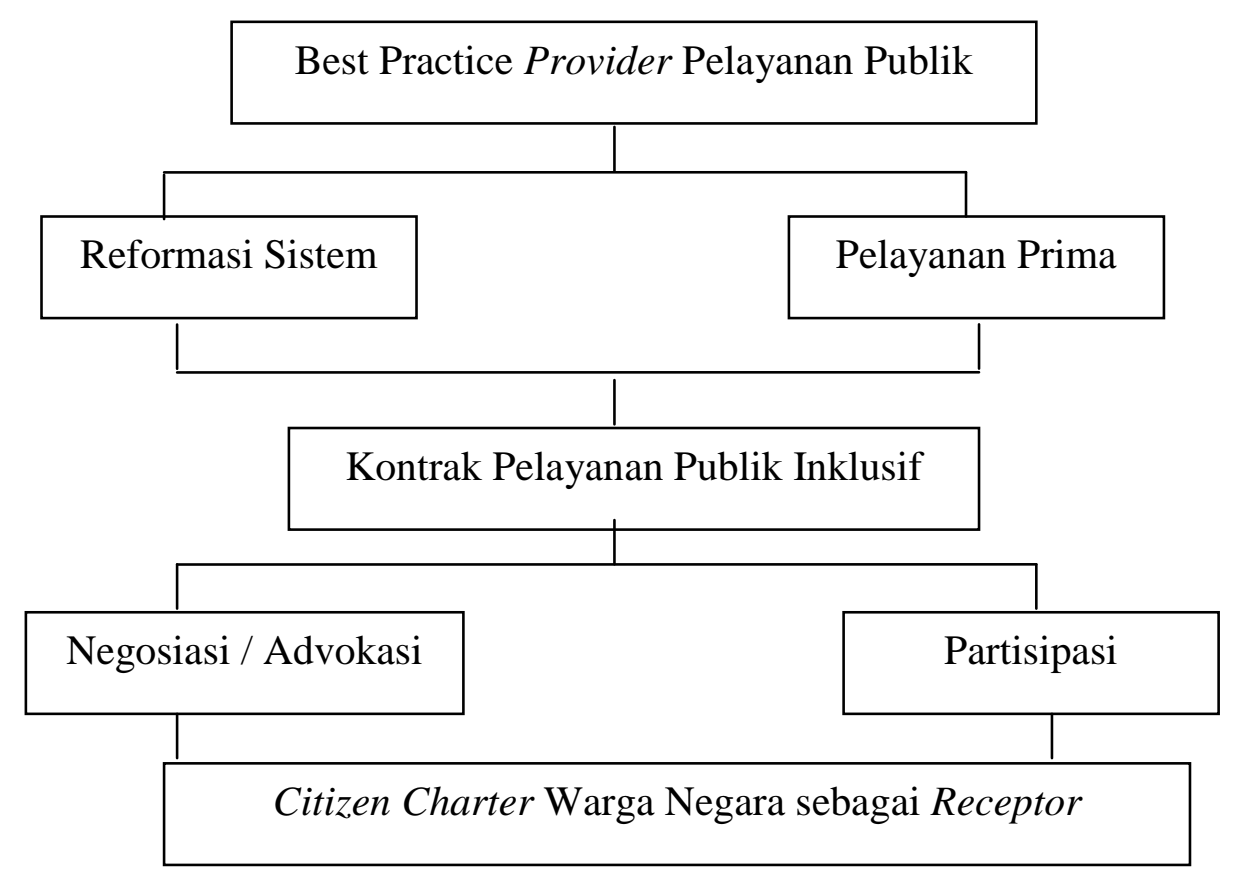

Sumber: (Karjuni, 2010) 
Kasus pelayanan publik berbasis citizen charter maupun best practice di Indonesia, dapat dicermati dalam tiga strategi besar yakni komitmen kepala daerah, restrukturisasi kelembagaan satu atap, dan pengeluaran kebijakan populis dan afirmatif bagi publik. Ketiga hal tersebut dapat terelaborasi dengan lebih mendetail dan komprehensif dalam membaca berbagai kasus pelayanan publik di era otonomi daerah. Kabupaten Sragen maupun Jembrana merupakan contoh riil dalam implementasi reformasi pelayanan publik, sekaligus reformasi sistem birokasinya. Adapun dalam kasus Jembrana, kasus best practice yang menonjol adalah pemberian kebijakan populis dan afirmatif seperti Jaminan Pendidikan Jembrana (JPJ) dan Jaminan Kesehatan Jembrana (JKJ) (Endarti, 2011:5).

Dalam kasus pendidikan, yang ditonjolkan adalah pemberian kebijakan sekolah gratis bagi penduduk hingga tingkat menengah di sekolah negeri dan pemberian subsidi bagi siswa sekolah swasta. Di bidang kesehatan adalah pemberian kebijakan berobat gratis bagi penduduk di tingkat puskemas maupu rumah sakit. Dalam kasus Sragen, yang ditekankan adalah restrukturisasi kelembagaan, terutama masalah perizinan. Hal itulah yang kemudian mendorong dibentuknya suatu institusi satu atap satu pintu, memungkinkan semua urusan perizinan berada di satu kantor dan dilaksanakan dengan cepat dan tepat. Pelayanan satu atap satu pintu ini adalah terobosan atas masalah perizinan yang selama ini dianggap bermasalah dan tidak menghasilkan solusi konkrit.

\section{Kesimpulan}

Pelayanan Publik merupakan bagian dari penerapan demokrasi di level praksis, pemenuhan basic needs bagi warga negara adalah esensinya. Untuk memaknai dimensi relasi warga negara dengan Negara, bisa dilihat melalui rezim regulatori yang dibangun baik itu liberal, sosio-demokrat, maupun investasi sosial. Kewargaan menjadi tolok ukur untuk menentukan seberapa jauh negara mengintervensi persoalan pemenuhan kebutuhan masyarakatnya. Secara garis besar, rezim regulatori terbagi tiga mahzab yang juga berbeda dalam mendefinisikan konteks kewargaannya.

Hadirnya kewargaan inklusif dalam model pelayanan publik merupakan bentuk respons atas gagalnya politik kewargaan yang dihimpun dalam rezim sebelumnya. Nilainilai seperti advokasi, negosiasi, maupun partisipatoris merupakan sebentuk nilai kewargaan inklusif tersebut. Pada level praksisnya, kemudian diterjemahkan dalam bentuk citizen charter maupun best practice, yang mengedepankan perbaikan dalam semua lini. Dalam konteks Indonesia, pelayanan publik berbasis kewargaan inklusif penerapannya masih terbatas dan masih berbasis urban. Hal ini adalah tantangan tersendiri dalam mendemokratiskan pelayanan publik berbasis kewargaan inklusif di Indonesia ke depannya.

\section{Daftar Pustaka}

Endarti, Esa. (2011). Kebijakan Publik dan Reformasi Administrasi: Studi Kasus pada Kabupaten Jembrana. Governance, Jurnal Kebijakan dan Manajemen Publik. Vol.2, No.1. Edisi April 2011.

Gaventa, John. (2002). Introduction; Exploring Citizenship, Participation and Accountability. IDS Bulletin. Vol. 33, No. 2.

Gøsta, Esping-Andersen. (1990). The Three Political Economies of the Welfare State. International Journal of Sociology. Vol. 20, No. 3.

Manow, Phillips \& Bernhard Ebbinghaus. (Eds.)/2001). Comparing Welfare Capitalism. London: Routledge.

Jati, Wasisto Raharjo. (2011). Inovasi Pelayanan Publik Setengah Hati: Studi Pelayanan Publik di SAMSAT Kota Yogyakarta. Jurnal 
Ilmu Sosial dan Ilmu Politik. Vol.15, No.1. Edisi. Juli-September.

Kumorotomo, Wahyudi. (2007, 16 Juni).

Citizen Charter (Kontrak Pelayanan): Pola

Kemitraan Strategis untuk Mewujudkan Good Governance dalam Pelayanan Publik. Makalah disampaikan di Seminar Persadi, Yogyakarta.

Maani, Karjuni. (2010). Citizen Charter:

Terobosan Baru dalam Penyelenggaran Layanan Publik. Jurnal Tingkap, Vol.6, No.2.
Pratikno. 2005. Good Governance \& Governability. Jurnal Ilmu Sosial dan Ilmu Politik. Vol.8, No.3. Edisi Juli-September.

Robert, Robertus \& Hendrik Tobi. (2014). Pengantar Sosiologi Kewarganegaraan: Dari Marx sampai Agamben. Jakarta: Penerbit Marjin Kiri.

Seidle, Leslie. 1995. Rethinking the Delivery of Public Services to Citizens. IRPP Press.

Zed, Mestika. (2004). Metode Penelitian Kepustakaan. Jakarta: Yayasan Obor. 